\title{
Current understanding of the surface contamination and contact transmission of SARS-CoV-2 in healthcare settings
}

\author{
Hosoon Choi ${ }^{1}$ Piyali Chatterjee ${ }^{1}$ John D. Coppin ${ }^{1}$. Julie A. Martel ${ }^{1}$ Munok Hwang ${ }^{1} \cdot$ Chetan Jinadatha $^{1}$. \\ Virender K. Sharma² ${ }^{2}$
}

Received: 28 December 2020 / Accepted: 15 January 2021 / Published online: 11 February 2021

(c) This is a U.S. government work and not under copyright protection in the U.S.; foreign copyright protection may apply 2021

\begin{abstract}
The novel coronavirus disease (COVID-19) has rapidly spread across the world and was subsequently declared as a pandemic in 2020. To overcome this public health challenge, comprehensive understanding of the disease transmission is urgently needed. Recent evidences suggest that the most common route of transmission for SARS-CoV-2 is likely via droplet, aerosol, or direct contact in a person-to-person encounter, although the possibility of transmission via fomites from surfaces cannot be ruled out entirely. Environmental contamination in COVID-19 patient rooms is widely observed due to viral shedding from both asymptomatic and symptomatic patients, and SARS-CoV-2 can survive on hospital surfaces for extended periods. Sequence of contact events can spread the virus from one surface to the other in a hospital setting. Here, we review the studies related to viral shedding by COVID-19 patients that can contaminate surfaces and survival of SARS-CoV-2 on different types of surfaces commonly found in healthcare settings, as well as evaluating the importance of surface to person transmission characteristics. Based on recent evidences from the literature, decontamination of hospital surfaces should constitute an important part of the infection control and prevention of COVID-19.
\end{abstract}

Keywords COVID-19 $\cdot$ Hospital surfaces $\cdot$ Decontamination $\cdot$ Droplet $\cdot$ Aerosols $\cdot$ Viral shedding

\section{Introduction}

The coronavirus infectious disease 2019 (COVID-19), first reported in Wuhan, China, has now spread to 227 countries and territories around the world, and the number of cases and deaths associated with COVID-19 keeps increasing ever since the WHO declared COVID-19 as a pandemic on March 11, 2020 (World Health Organization 2020a). COVID-19 is caused by a new type of coronavirus, severe acute respiratory syndrome coronavirus-2 (SARS-CoV-2). Despite millions of cases, many factors are unknown about the transmission

Chetan Jinadatha

chetan.jinadatha@va.gov

$\bowtie$ Virender K. Sharma

vsharma@tamu.edu

1 Department of Research, Central Texas Veterans Health Care System, 1901 Veterans Memorial Drive, Temple, TX, USA

2 Program of the Environment and Sustainability, Department of Environmental and Occupational Health, School of Public Health, Texas A\&M University, College Station, TX 77843, USA of the disease producing massive uncertainty in prevention efforts of the spread of the virus. SARS-CoV-2 shares some aspects with previous epidemic coronavirus such as Middle Eastern respiratory syndrome coronavirus (MERS-CoV) and SARS-CoV-1 that occurred in the early 2000's. However, the transmission of SARS-CoV-2 is markedly different from that of the other coronaviruses. Understanding of SARS-CoV-2 transmission is critical to institute effective control measures for preventing the spread of COVID-19.

SARS-CoV-2 enters the body through the nose, mouth or eyes and spreads to the lining of the nose, sinus cavity, and throat (Kaur et al. 2020). Initial symptoms often include fever, dry cough, sore throat, loss of smell and taste, or head and body aches (Qian et al. 2020b; The COVID-19 Investigation Team 2020; Zhou et al. 2020a). In the first week or so, the virus can attack lungs and result in pneumonia. Heart and blood vessels are also vulnerable to infection (Mokhtari et al. 2020). Damage of kidney, gastrointestinal system, brain and nervous system is very frequently observed in COVID19 patients. Patients with pre-existing pulmonary disease or with blood vessel damage, diabetes and high blood pressure, appear to have higher risk of serious disease (Zaim 
et al. 2020). SARS-CoV-2 disproportionately impacts older people and people with immune deficiency (Fig. 1) (Zaim et al. 2020; Zhou et al. 2020a).

According to a statement released by World Health Organization (WHO) in January 2020, the initial estimated $\mathrm{R}_{0}$, an indication of how contagious an infectious disease, for COVID-19 was 1.4-2.5 (World Health Organization 2020c). This initial estimation was lower than previous coronavirus outbreaks like the SARS-CoV-1 $\left(\mathrm{R}_{0} 2-5\right)$ but higher than that of MERS-CoV $\left(R_{0}\right.$ less than 1) (Bauch and Oraby 2013; Sattar 2001). Current systematic reviews indicate that the mean $R_{0}$ has increased to $3.38 \pm 1.40$, with a range of 1.90-6.49 (Alimohamadi et al. 2020). Estimated $R_{0}$ supports WHO's statement that SARS-CoV-2 is predominantly spread through person-to-person transmission (World Health Organization 2020d).

The factors that affect the modes of transmission include characteristics of the virus strain itself, host population, and interplay with the environment. The features of the virus such as the ability to infect the host, survivability, viral shedding, and host factors such as susceptibility and behavior contributes to the spread. In addition, environmental factors such as host density and movement patterns play a pivotal role in the spread (Spicknall et al. 2010). In the case of COVID-19, respiratory droplets, generated when infected persons cough, sneeze, talk or sing, which can then reach the mouth, nose or eyes of susceptible persons, are considered to be playing a major role in the spread of this infection. Transmission through respiratory droplet occurs over distances of no more than 3 or 4 feet. Aerosol transmission is also now recognized as a mode of spread (Klompas et al. 2020;

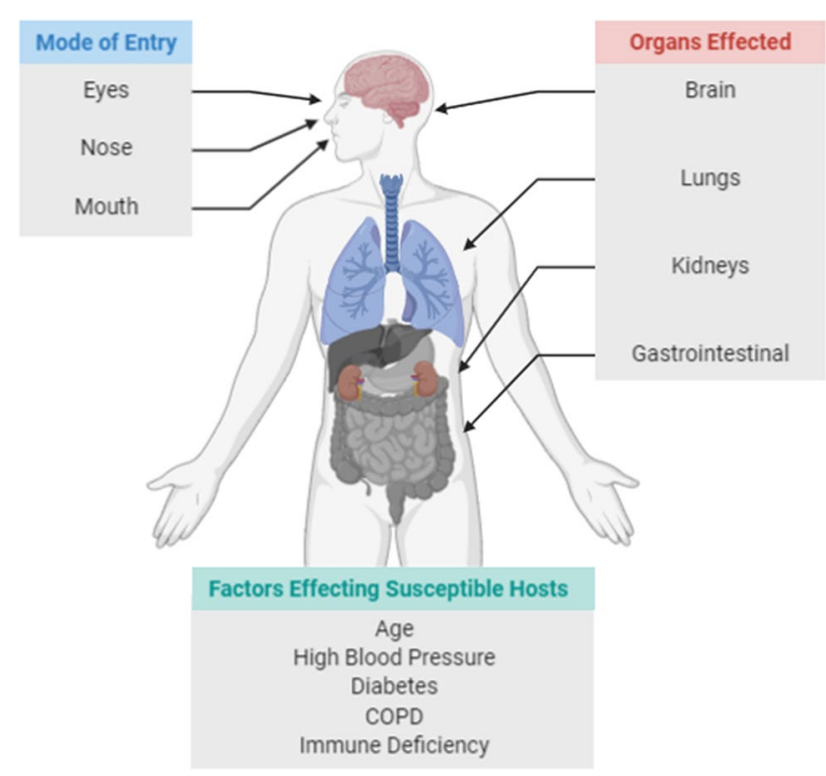

Fig. 1 The modes of entry, contributing factors, and organs affected in SARS-CoV-2 infection
Tang et al. 2020). However, other modes of transmission are possible including indirect contact transmission involving contaminated objects or surfaces.

The existing data for indirect method of transmission for respiratory viruses are mostly limited but some evidences through stochastic transmission models and review of literature have suggested a possible mode of transmission through fomites for influenza viruses (Brankston et al. 2007; Bridges et al. 2003). The transfer of infectious viruses may readily occur once a fomite is contaminated. Fomites can be contaminated with virus by direct contact with body secretions or fluids, contact with SARS-CoV-2 contaminated hands, or respiratory droplets landing directly on surfaces (Goldmann 2000; Sattar 2001). However, direct experimental evidence of viral transmission of human infection via fomite is very difficult to establish due to widespread community transmission. In this review, we will discuss experimental and observational evidences gathered so far on transmission of COVID-19. These efforts will allow us not only to identify the sources of transmission but also help formulate effective strategies and institutional guidelines for infection prevention.

\section{Shedding of SARS-CoV-2}

Understanding viral shedding is important to optimize the treatment and prevent transmission. The reverse transcription polymerase chain reaction (RT-PCR) assays of SARSCoV-2 RNA have been extensively used to demonstrate the presence of the virus due to its high sensitivity. The studies found SARS-CoV-2 in respiratory samples, saliva, blood, feces, and rarely from urine (Pan et al. 2020; The COVID19 Investigation Team 2020; To et al. 2020; Zheng et al. 2020; Zou et al. 2020). SARS-CoV-2 was detected from the pre-symptomatic period (Pan et al. 2020) and lasted significantly after symptom resolution (Fig. 2) (Dou et al. 2020; Lan et al. 2020; Li et al. 2020). The median duration of viral shedding in respiratory samples was 12-24 days (Gombar et al. 2020; Hu et al. 2020a; Lo et al. 2020; Qi et al. 2020; Qian et al. 2020a; The COVID-19 Investigation Team 2020; Xiao et al. 2020b; Xu et al. 2020; Zheng et al. 2020; Zhou et al. 2020a). The longest reported duration was 67 days (Perera et al. 2020). Duration of the virus in the respiratory samples was significantly longer in patients with severe disease (median 21 days, 14-30 days) compared to patients with milder disease (14 days, 10-21 days; $P=0.04$ ) (Zheng et al. 2020). Among patients with severe symptoms, the duration of the viral shedding was significantly longer in male patients (Xu et al. 2020; Zheng et al. 2020), older age (Xiao et al. 2020a, 2020b; Xu et al. 2020; Zheng et al. 2020), and in patients on glucocorticoids 


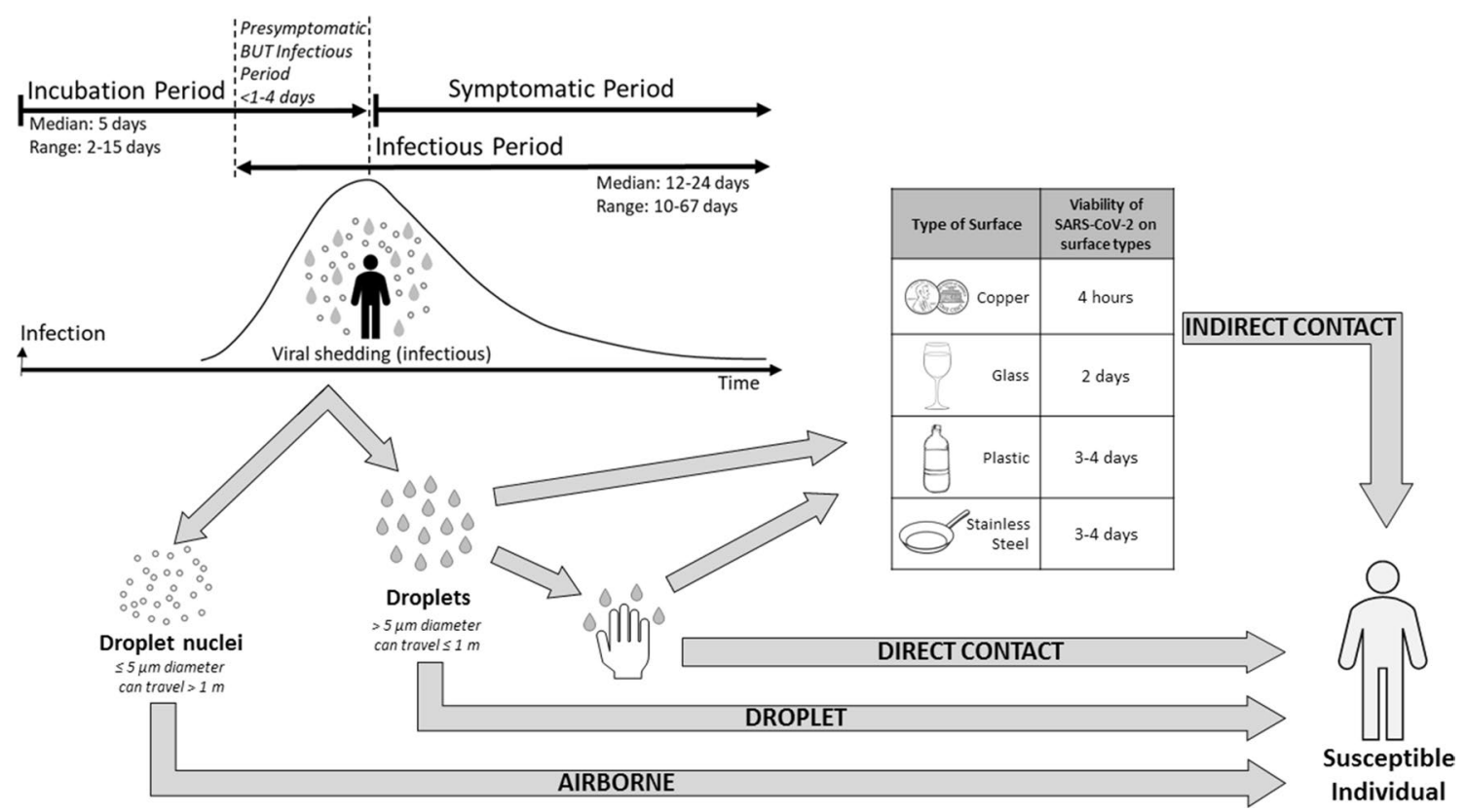

Fig. 2 Modes and duration of transmission in SARS-CoV-2 infection

treatment (Xu et al. 2020; Zheng et al. 2020), with longer time from symptom onset to hospital admission (Qi et al. 2020; Xu et al. 2020).

Significantly, the detection of viral RNA does not necessarily equate to infectious viruses being present (Atkinson and Peterson 2020). Presence of infectious viruses can be undoubtedly confirmed by cell culture, but it is difficult and expensive. Live virus isolation from throat swabs provide evidence of the virus replication in the upper respiratory tract (Bullard et al. 2020; Perera et al. 2020; Wolfel et al. 2020). To distinguish viable virus from non-viable virus using PCR, RT-PCR tests for subgenomic mRNA can be applied. Viral subgenomic mRNA indicates the presence of actively infected cells in samples since subgenomic RNA is transcribed only in infected cells and is not present in virions (Kim et al. 2020). The subgenomic mRNA of SARS$\mathrm{CoV}-2$ was detected in the upper respiratory samples and this indicates that active replication of SARS-CoV-2 occurs in the upper respiratory tract (Doddapaneni et al. 2020; Perera et al. 2020; Wolfel et al. 2020), whereas replication of SARS-CoV-1 mainly occurs in the lower respiratory tract (Cheng et al. 2004). The replication in the upper respiratory tract makes SARS-CoV-2 more transmissible. The live SARS-CoV-2 was isolated during the first week of symptoms from swabs and sputum samples while no live SARS-CoV-2 was detected 8 days after symptom onset (Bullard et al. 2020; He et al. 2020; Perera et al. 2020; Sun et al. 2020; Wolfel et al. 2020). The subgenomic mRNA of SARS-CoV-2 was also detected up to 8 days after the onset of symptoms (Perera et al. 2020).
The high viral load in respiratory samples was observed at the time of symptom onset, but, viral loads gradually decreased during the disease progression (He et al. 2020; To et al. 2020; Wolfel et al. 2020; Zheng et al. 2020; Zou et al. 2020). Overall, high $\left(>1 \times 10^{6}\right.$ copies per $\left.\mathrm{mL}\right)$ viral load was detected from early days of infection (Pan et al. 2020). The viral load in respiratory samples continued to be high during the third and fourth weeks after disease onset in patients with severe disease but the viral load was reduced after the second week in patients with mild disease (Zheng et al. 2020). Temporal profile of viral load corresponded well to the dynamics of SARS-CoV-2 infectiousness. The infectiousness of SARS-CoV-2 starts from 1 to 4 days before symptom onset (Byrne et al. 2020) and peaked at 2 days before to 1 day after symptom onset and declined within 7 days (He et al. 2020). The median incubation period of COVID-19 is estimated to be 5 days with the $95 \%$ range spanning from 2 to 14 days (Linton et al. 2020). The long incubation period and the high infectivity of SARS-CoV-2 during the incubation period make implementing the preventive measure difficult. Proportion of pre-symptomatic transmission was estimated to be $37-48 \%$ of transmission (He et al. 2020).

Furthermore, a significant portion of infected persons show no symptom but could still shed viruses (Zhou et al. 2020c). Asymptomatic infections were estimated at 15-30\% (Chen et al. 2020; Long et al. 2020; Mizumoto et al. 2020; Nishiura et al. 2020). However, asymptomatic infection may be more common than the current estimation. In Vo', Italy, 43 percent of surveyed town residents tested positive 
despite having no symptoms (Lavezzo et al. 2020). Furthermore, when all passengers and crew were COVID-19 tested in a cruise ship, $80 \%$ of the COVID-19-positive patients were asymptomatic (Ing et al. 2020). A recent review indicated that the asymptomatic patients could account for up to $45 \%$ of infections (Oran and Topol 2020). Viral transmission by asymptomatic carriers has also been reported in many studies (Bai et al. 2020; Hu et al. 2020c; Lavezzo et al. 2020; Qian et al. 2020b; Rothe et al. 2020; Tong et al. 2020). Some investigations indicate transmission rates by asymptomatic patients are as high as symptomatic patients (Chen et al. 2020; Yin and Jin 2020) while others estimate the rate as one third of that of symptomatic transmissions (Wu 2020). Indeed, there is no significant difference in viral load between asymptomatic and symptomatic groups (Zou et al. 2020) while the asymptomatic group shed virus significantly longer than the symptomatic group (Long et al. 2020). Those results indicate that the symptom-based screening is not enough to control transmission.

SARS-CoV-2 was also detected from stool (53-59\%) and serum (40-59\%) in a significant fraction of patients (Lo et al. 2020; Pan et al. 2020; To et al. 2020; Wang et al. 2020; Wolfel et al. 2020; Zhang et al. 2020b; Zheng et al. 2020). The positive rates for stool and serum samples gradually increased during the first week and decreased from the third week onwards (Zheng et al. 2020). The live virus has been isolated from stool samples (Wolfel et al. 2020; Xiao et al. 2020c). Very few critically ill patients have detectable virus RNA in their urine samples (Zheng et al. 2020). The viral load of stool samples peaked during the third and fourth week after disease onset (Zheng et al. 2020). The median duration of viral shedding in the stool samples was significantly longer than from respiratory and serum samples; 22 days (interquartile range 17-31 days) in stool, 18 days (interquartile range 13-29 days) in respiratory, and 16 days (interquartile range 11-21 days) in serum (Zheng et al. 2020).

\section{Environmental contamination of SARS-CoV-2}

Patients can be either pre-symptomatic, symptomatic, paucisymptomatic, and asymptomatic shedding viruses in their vicinity. Environmental contamination in occupied patient rooms is known to be higher in the first week of illness for COVID-19 patients than the subsequent period of their stay due to high viral shedding. Persistence of viruses on the surfaces for a few days may promote transmission from these surfaces to healthcare workers (HCWs) to other patients. In addition, patients often share common spaces, therefore fomites can spread through touch contamination followed by self-inoculation of the mucous membranes.
The results of transmissibility of coronaviruses from contaminated surfaces in hospital settings are now emerging. Previous large outbreaks of MERS and SARS-CoV-1 have similarly been driven by the nosocomial spread. These studies confirmed that the environmental contamination is common. Some common themes have emerged from recent studies of hospitalized COVID-19 patients in several countries including China, England and Italy (Li et al. 2020; Razzini et al. 2020; Zhou et al. 2020b). High-touch surfaces of hospitals are likely to be more contaminated than the low-touch surfaces (Tan et al. 2020). Moreover, within the hospital, intensive care units (ICUs) have the highest positivity of viruses, followed by isolation wards. A very little viral RNA was recovered from other areas of the hospital such as common areas, nursing stations, corridors, and anterooms. Patients with severe COVID-19 symptoms tend to spread more viruses around them versus patients with milder symptoms. Interestingly, asymptomatic patients have been found to shed viruses in the environment which can also lead to further spread. In most studies, viable viruses have not been recorded (Wei et al. 2020). The lack of viable viruses may be due to desiccation and death of the viruses at the time of collection. However, one study was able to recover viable viruses thus far. As mentioned earlier, transiently contaminated hands of healthcare workers are likely to have important implications for the viral spread. Other areas include floors around bathroom toilets where the presence of viral RNA have been reported. Therefore, adherence to strict environmental cleaning policies is needed and routine hospital surface disinfection methods have been shown to decrease the presence of viruses on contaminated surfaces efficiently (Ryu et al. 2020). In fact, one study depicts environmental sampling done after cleaning tested negative with no viral particles being recovered, whereas, if done prior to cleaning it yielded positive results with recovery of viral RNA (Hu et al. 2020b). In addition, higher viral load in patients corresponds to higher positivity rates of recovery of viral RNA from surfaces.

Fecal matter/stool samples from the toilet bowl, sink and door handles were found to be positive for SARSCoV-2 by the PCR technique. Two possible contamination routes include either respiratory droplets contaminating the toilet or environmental fecal contamination. The fecal contamination, caused by an infected person, also caused the spread of the SARS-CoV-2 virus (Zhang et al. 2020a). There is a possibility that larger outbreak can happen from viral stool shedding that can lead to sewage contamination. These findings contrast earlier reports by the WHO, which did not support the fecal-oral transmission of the SARSCoV-2 virus (World Health Organization 2020b). 


\section{Survival of SARS-CoV-2 on healthcare surfaces}

The indirect modes of transmission of coronaviruses through surface contamination/fomites have been controversial. Recent evidences suggest that most viruses such as coronaviruses, coxsackieviruses, influenza virus, MERS, and rhinoviruses can be present on the surfaces for prolonged periods of time. The fact that these viruses can survive for prolonged periods of time on different surfaces suggest that they can serve as possible reservoirs for onward transmission from surfaces to human (Kramer et al. 2006).

The duration that coronaviruses (SARS-CoV-1, MERS, SARS-CoV-2) persist on surfaces has been studied in vitro over the years (Chan et al. 2011; Coulliette et al. 2013; van Doremalen et al. 2020). Different surfaces made of plastics and metals demonstrated variable viral survivability. Typically, the type of test material has an influence on the survival of the viruses depending on their porosity. A comparison of survivability of the coronaviruses on different types of dry surfaces is included as a table (Table 1). In general, survival of these viruses on plastic is longer than on steel. Interestingly, survival times for coronaviruses on copper surfaces have been consistently found to be the shortest, suggesting copper surfaces may be beneficial in preventing transmission (Noyce et al. 2007). Other experimental factors that have been shown to influence virus viability in vitro include longer persistence of the viruses with higher inoculum, in presence of protein, serum, sputum or without dust (Casanova et al. 2010; Rabenau et al. 2005). Lower temperatures improved survival of these viruses. Relative humidity is also an important factor that contributes to the virus survival. There have been reports of strain variation on survivability of influenza viruses, but this is largely unknown for coronaviruses (Coulliette et al. 2013; Dublineau et al. 2011).

Several methods have been employed to detect the presence of coronaviruses on various surfaces. The vast majority of the studies to date have used real-time PCR assays that can detect the virus as well as determine the viral load (Zuo et al. 2013). However, whether the virus is viable is not known when using this method (PCR). Cell culture methods are usually used to detect the presence of viable viruses. It is of paramount importance to determine the infectivity of each virus because the mere presence of the viral RNA on a surface does not signify that they can be transmitted and infect another person. Several other newer methods using CRISPR (Dara and Talebzadeh 2020) based diagnostic assays and loop mediated isothermal amplification (Lu et al. 2020; Yan et al. 2020; Yu et al. 2020) are also being applied for detecting the virus. Future studies on persistence of coronaviruses outside of its host are needed to define the role of contaminated surfaces on the transmission like those observed in cases of influenza and parainfluenza viruses.

\section{Transmission characteristics of surface-to-person transmission}

Larger droplets deposited onto surfaces via gravitational sedimentation occur relatively close to the emitter. This is likely a common contamination route for items within 2-6 $\mathrm{m}$ distance from the individual who coughs or sneezes (Xie et al. 2007). However, aerosolized particles less than $5 \mu \mathrm{m}$ can also deposit on surfaces. Mathematical models, based on information from studies taking sputum and swab samples, suggest that the typical emitter who is asymptomatic may emit enough virus through normal breathing to

Table 1 Persistence of coronaviruses on commonly used hospital surfaces under different environmental conditions

\begin{tabular}{|c|c|c|c|c|}
\hline Type of surface & $\mathrm{HCoV}-229 \mathrm{E}$ & SARS-CoV-1 & MERS-CoV & SARS-CoV-2 \\
\hline Plastic & $\begin{array}{l}2 \mathrm{~d}, 5 \mathrm{~d} \\
\text { Rabenau et al. (2005) } \\
\text { Warnes et al. (2015) }\end{array}$ & $\begin{array}{l}6 \mathrm{~d}, 4 \mathrm{~d}, 3 \mathrm{~d}, 28 \mathrm{~d}, 1 \mathrm{~d} \\
\text { Duan et al. (2003) } \\
\text { van Doremalen et al. (2020) } \\
\text { Chan et al. (2011) }\end{array}$ & $\begin{array}{l}2 \mathrm{~d}, 8 \mathrm{~h}, 1 \mathrm{~d} \\
\text { van Doremalen et al. (2013) } \\
\text { van Doremalen et al. (2020) }\end{array}$ & $\begin{array}{l}3 \mathrm{~d}, 4 \mathrm{~d} \\
\text { van Doremalen et al. (2020) } \\
\text { Chin et al. (2020) }\end{array}$ \\
\hline Stainless steel & $\begin{array}{l}5 \mathrm{~d} \\
\text { Warnes et al. (2015) }\end{array}$ & $\begin{array}{l}2 \mathrm{~d} \\
\text { van Doremalen et al. (2020) }\end{array}$ & $\begin{array}{l}8 \mathrm{~h}, 1 \mathrm{~d}, 2 \mathrm{~d} \\
\text { van Doremalen et al. (2013) }\end{array}$ & $\begin{array}{l}3 \mathrm{~d}, 4 \mathrm{~d} \\
\text { van Doremalen et al. (2013) } \\
\text { Chin et al. (2020) }\end{array}$ \\
\hline Copper & $\begin{array}{l}20 \mathrm{~min}, 30 \mathrm{~min}, 1 \mathrm{~h} \\
\text { Warnes et al. (2015) }\end{array}$ & $\begin{array}{l}8 \mathrm{~h} \\
\text { van Doremalen et al. (2020) }\end{array}$ & - & $\begin{array}{l}4 \mathrm{~h} \\
\text { van Doremalen et al. (2020) }\end{array}$ \\
\hline Glass & $\begin{array}{l}5 \mathrm{~d} \\
\text { Warnes et al. (2015) }\end{array}$ & $\begin{array}{l}4 \mathrm{~d} \\
\text { Duan et al. (2003) }\end{array}$ & - & $\begin{array}{l}2 \mathrm{~d} \\
\text { Chin et al. (2020) }\end{array}$ \\
\hline Aluminum & $\begin{array}{l}2 \mathrm{~h}, 6 \mathrm{~h} \\
\text { Sizun et al. (2000) }\end{array}$ & - & - & - \\
\hline Brass & $\begin{array}{l}10 \text { min, } 15 \text { min, } 2 \mathrm{~h} \\
\text { Warnes et al. (2015) }\end{array}$ & - & - & - \\
\hline
\end{tabular}


produce a concentration of 0.0043 copies $/ \mathrm{m}^{3}$ of virus in a room with a normal air exchange rate or 0.000758 copies $/ \mathrm{m}^{3}$ in a room with similar air exchange rate as a hospital (Lopez et al. 2013). Under the same scenarios, they estimated that a high emitter may emit enough virus through normal breathing such that the concentration in a room is 560 copies $/ \mathrm{m}$ and in a hospital room is 99 copies $/ \mathrm{m}^{3}$. Frequent coughing from this high emitter boosts the estimate to more than 588,000 copies $/ \mathrm{m}^{3}$ in a hospital room. While this potentially poses risk of airborne transmission to anyone in the room as these particles remain suspended for long periods of time, some also settle onto surfaces, contaminating the surface. Thus, surfaces can be contaminated both by droplets and small aerosolized microdroplets.

Surfaces may also be contaminated via direct contact from the person to the surface. Julian et al. studied the transfer fraction $((f=\mathrm{Rr} /(\mathrm{Rr}+\mathrm{Rd})$ where $\mathrm{Rr}$ is the recipient surface and $R d$ is the donor surface) for 3 different phages to determine the transfer efficiency of the phages from a person's skin to glass and vice versa (Julian et al. 2010). Using high and low inoculated surfaces of between 100 and 600 or 1000 and $6000 \mathrm{PFU}$ in $5 \mu \mathrm{l}$, and allowed to dry, they determined the overall mean transfer fraction for all three phages combined was 0.23 with a standard deviation of 0.20 . Results from similar experiments that loaded much greater $\left(10^{11} \mathrm{pfu}\right)$ amounts of MS2 phage gave similar results as the above study under low relative humidity for transfer from fomite to finger for glass (19.3\% (13.2\%)), and in addition, they looked at a variety of surface types and humidity to understand how these factors might change the transfer efficiency (Julian et al. 2010). Under high relative humidity, the transfer increased to $67.3 \%$ (25.0\%). The transfer also varied greatly with the type of fomite. Under low humidity, acrylic $(21.7 \%(15.0 \%))$ and glass $(19.3 \%(13.2 \%))$ had greater transfer efficiency than other non-porous surfaces like ceramic tile $(7.1 \%(4 \%))$, laminate $(5.4 \%(3.6 \%))$, stainless steel $(6.9 \%(8.9 \%))$, and granite $(10.2 \%(5 \%))$.

Porous surfaces had very low transfer efficiencies with cotton $(0.03 \%(0.02 \%))$, polyester $(0.3 \%(0.2 \%))$, and paper currency $(0.4 \%(0.4 \%))$ all being similar. Under high humidity, the transfer efficiency increased across all materials except for cotton, with little effect on the porous surfaces, but large increases on the non-porous surfaces with acrylic $(79.5 \%(21.2 \%))$, glass $(67.3 \%(25 \%))$, ceramic tile $(41.2 \%(18.8 \%))$, laminate $(63.5 \%(24 \%))$, stainless steel $(37.4 \%(16 \%))$, and granite $(30 \%(24.3 \%))$ all showing marked increases in transfer efficiency. In a more real-world approach, Rusin et al. showed that participants performing tasks (such as turning the faucet on/off and holding a phone receiver) that involved inoculated objects showed the highest transfer efficiencies for the phage from hard surfaces (faucet $33 \%$ and phone receiver 66\%) (Rusin et al. 2002). The same study also showed $34 \%$ transfer efficiency of phage from inoculated fingertip to lip. Thus, contamination of surfaces via direct contact is very probable, especially for high-touch surfaces.

So-called high-touch surfaces have been described by several studies (Jinadatha et al. 2017; John et al. 2017). Certain surfaces, particularly bed-parts such as bedrails, receive a large amount of contact both by the patient and the healthcare workers. Touches to a surface generally do not occur in isolation, but rather as part of a sequence of touches involving a variety of fomites. For example, when studying touch sequences of healthcare workers, a sequence could be defined as all of the touches a healthcare worker performs between their entry into a patient room and their exit (Jinadatha et al. 2017). During this time period, they may touch more than a dozen items in the room. Within these long sequences are sub-sequences of touches that occur more frequently. For example, Jinadatha et al. reported that the most common sub-sequence within a patient care sequence was touching the patient and then the bedrail $(28.1 \%$ of all patient care sequences contained this sub-sequence) or touching the bedrail and then the patient $(26.3 \%$ of all patient care sequences contained this sub-sequence) (Jinadatha et al. 2017). Touching a computer-on-wheels portable medical device and then the patient was the 5th most common sub-sequence. These findings demonstrate how interrelated all the items are in a room in terms of touch contacts. Given a certain probability to transfer a pathogen from a hand to a surface (as described in the transfer efficiency studies above), then it is possible that pathogens could be transferred to a surface and then to the patient or to another surface and then the patient. If the fomite is a portable medical equipment (PME), then it may be brought into multiple patient rooms where the sequence of touches involves touching the portable medical equipment and then the patient or a surface that the patient may later touch.

As an oversimplified example, imagine a situation where a healthcare worker touched a contaminated fomite that contained 1,000 COVID-19 virus, subsequently touched a patient bedrail, and then the patient touched the same bedrail. Using a point estimated mean transfer efficiency of 0.23 , $1000 * 0.23$ (to healthcare worker hand) $* 0.23$ (healthcare worker to patient bedrail) $* 0.23$ (bedrail to patient hand) $=12$ virus on the patient's hand. This oversimplified example, of course, makes many assumptions, particularly that the virus contact spot was touched completely on each subsequent surface and that the transfer efficiency was exactly 0.23 at each transfer. Even so, it is not hard to imagine the possibility of multiple fomites being contaminated in sequence via a variety of vectors. The studies detailed above reveal large standard deviations in the reported transfer efficiencies, so when this error is included and propagated through an example like the above, rather than just using a point estimated transfer efficiency, then it is quite possible to 
calculate anywhere from zero virus transferred to a rather large number. Thus, based on the available data, estimating the transfer of virus through a series of transfer events would be speculative at best. However, these studies do reveal that transfer through a series of events is quite possible.

Indeed, sequences of contact events where a fraction of pathogen is transferred with each successive touch as described above likely explain the findings by multiple studies that have reported widespread contamination of objects in the patient room, common work areas, and on portable medical equipment in the hospital after inoculating a few surfaces with cauliflower mosaic virus DNA markers (John et al. 2017; Oelberg et al. 2000).

Acknowledgments We thank Morgan Bennett for her contribution in creating figures. This publication was supported by the resources of the Central Texas Veterans Health Care System (Temple, TX); the Central Texas Veterans Health Care System Research Service. The views expressed in this article are those of the author(s) and do not necessarily represent the views of the Department of Veterans Affairs.

\section{References}

Alimohamadi Y, Taghdir M, Sepandi M (2020) Estimate of the basic reproduction number for COVID-19: a systematic review and meta-analysis. J Prev Med Public Health 53(3):151-157. https:// doi.org/10.3961/jpmph.20.076

Atkinson B, Petersen E (2020) SARS-CoV-2 shedding and infectivity. Lancet 395(10233):1339-1340. https://doi.org/10.1016/S0140 $-6736(20) 30868-0$

Bai Y, Yao L, Wei T, Tian F, Jin DY, Chen L, Wang M (2020) Presumed asymptomatic carrier transmission of COVID-19. JAMA 323(14):1406-1407. https://doi.org/10.1001/jama.2020.2565

Bauch CT, Oraby T (2013) Assessing the pandemic potential of MERSCoV. Lancet 382(9893):662-664. https://doi.org/10.1016/S0140 $-6736(13) 61504-4$

Brankston G, Gitterman L, Hirji Z, Lemieux C, Gardam M (2007) Transmission of influenza A in human beings. Lancet Infect Dis 7(4):257-265. https://doi.org/10.1016/S1473-3099(07)70029-4

Bridges CB, Kuehnert MJ, Hall CB (2003) Transmission of influenza: implications for control in health care settings. Clin Infect Dis 37(8):1094-1101. https://doi.org/10.1086/378292

Bullard J, Dust K, Funk D, Strong JE, Alexander D, Garnett L, Boodman C, Bello A, Hedley A, Schiffman Z et al (2020) Predicting infectious SARS-CoV-2 from diagnostic samples. Clin Infect Dis. https://doi.org/10.1093/cid/ciaa638

Byrne AW, McEvoy D, Collins AB, Hunt K, Casey M, Barber A, Butler F, Griffin J, Lane EA, McAloon C et al (2020) Inferred duration of infectious period of SARS-CoV-2: rapid scoping review and analysis of available evidence for asymptomatic and symptomatic COVID-19 cases. BMJ Open 10(8):e039856. https://doi. org/10.1136/bmjopen-2020-039856

Casanova L, Rutala WA, Weber DJ, Sobsey MD (2010) Coronavirus survival on healthcare personal protective equipment. Infect Control Hosp Epidemiol 31(5):560-561. https://doi. org/10.1086/652452

Chan KH, Peiris JS, Lam SY, Poon LL, Yuen KY, Seto WH (2011) The effects of temperature and relative humidity on the viability of the SARS coronavirus. Adv Virol 2011:734690. https://doi. org/10.1155/2011/734690
Chen Y, Wang AH, Yi B, Ding KQ, Wang HB, Wang JM, Shi HB, Wang SJ, Xu GZ (2020) Epidemiological characteristics of infection in COVID-19 close contacts in Ningbo city. Zhonghua Liu Xing Bing Xue Za Zhi 41(5):667-671. https://doi.org/10.3760/ cma.j.cn112338-20200304-00251

Cheng PK, Wong DA, Tong LK, Ip SM, Lo AC, Lau CS, Yeung EY, Lim WW (2004) Viral shedding patterns of coronavirus in patients with probable severe acute respiratory syndrome. Lancet 363(9422):1699-1700. https://doi.org/10.1016/S0140 -6736(04)16255-7

Chin AWH, Chu JTS, Perera MRA, Hui KPY, Yen HL, Chan MCW, Peiris M, Poon LLM (2020) Stability of SARS-CoV-2 in different environmental conditions. Lancet Microbe 1(1):e10. https://doi. org/10.1016/S2666-5247(20)30003-3

Coulliette AD, Perry KA, Edwards JR, Noble-Wang JA (2013) Persistence of the 2009 pandemic influenza A (H1N1) virus on N95 respirators. Appl Environ Microbiol 79(7):2148-2155. https://doi. org/10.1128/AEM.03850-12

Dara M, Talebzadeh M (2020) CRISPR/Cas as a potential diagnosis technique for COVID-19. Avicenna J Med Biotechnol 12(3): 201-202. Retrieved from https://www.ncbi.nlm.nih.gov/pubme $\mathrm{d} / 32695284$

Doddapaneni H, Cregeen SJ, Sucgang R, Meng Q, Qin X, Avadhanula V, Chao H, Menon V, Nicholson E, Henke D et al (2020) Oligonucleotide capture sequencing of the SARS-CoV-2 genome and subgenomic fragments from COVID-19 individuals. bioRxiv. https://doi.org/10.1101/2020.07.27.223495

Dou P, Zhang S, Wang C, Cai L, Liu Z, Xu Q, Li X, Meng Y, Rong Y, Li S et al (2020) Serial CT features in discharged COVID-19 patients with positive RT-PCR re-test. Eur J Radiol 127:109010. https://doi.org/10.1016/j.ejrad.2020.109010

Duan SM, Zhao XS, Wen RF, Huang JJ, Pi GH, Zhang SX, Han J, Bi SL, Ruan L, Dong XP, et al. (2003) Stability of SARS coronavirus in human specimens and environment and its sensitivity to heating and UV irradiation. Biomed Environ Sci 16(3): 246-255. Retrieved from https://www.ncbi.nlm.nih.gov/pubmed/14631830

Dublineau A, Batejat C, Pinon A, Burguiere AM, Leclercq I, Manuguerra JC (2011) Persistence of the 2009 pandemic influenza A (H1N1) virus in water and on non-porous surface. PLoS ONE 6(11):e28043. https://doi.org/10.1371/journal.pone.0028043

Goldmann DA (2000) Transmission of viral respiratory infections in the home. Pediatr Infect Dis J 19(10 Suppl):S97-102. https://doi. org/10.1097/00006454-200010001-00002

Gombar S, Chang M, Hogan CA, Zehnder J, Boyd S, Pinsky BA, Shah NH (2020) Persistent detection of SARS-CoV-2 RNA in patients and healthcare workers with COVID-19. J Clin Virol 129:104477. https://doi.org/10.1016/j.jcv.2020.104477

He X, Lau EHY, Wu P, Deng X, Wang J, Hao X, Lau YC, Wong JY, Guan Y, Tan X et al (2020) Temporal dynamics in viral shedding and transmissibility of COVID-19. Nat Med 26(5):672-675. https ://doi.org/10.1038/s41591-020-0869-5

Hu X, Xing Y, Jia J, Ni W, Liang J, Zhao D, Song X, Gao R, Jiang $\mathrm{F}$ (2020a) Factors associated with negative conversion of viral RNA in patients hospitalized with COVID-19. Sci Total Environ 728:138812. https://doi.org/10.1016/j.scitotenv.2020.138812

Hu X, Xing Y, Ni W, Zhang F, Lu S, Wang Z, Gao R, Jiang F (2020b) Environmental contamination by SARS-CoV-2 of an imported case during incubation period. Sci Total Environ 742:140620. https://doi.org/10.1016/j.scitotenv.2020.140620

Hu Z, Song C, Xu C, Jin G, Chen Y, Xu X, Ma H, Chen W, Lin Y, Zheng Y et al (2020c) Clinical characteristics of 24 asymptomatic infections with COVID-19 screened among close contacts in Nanjing, China. Sci China Life Sci 63(5):706-711. https://doi. org/10.1007/s11427-020-1661-4 
Ing AJ, Cocks C, Green JP (2020) COVID-19: in the footsteps of Ernest Shackleton. Thorax 75(8):693-694. https://doi.org/10.1136/thora xjnl-2020-215091

Jinadatha C, Villamaria FC, Coppin JD, Dale CR, Williams MD, Whitworth R, Stibich M (2017) Interaction of healthcare worker hands and portable medical equipment: a sequence analysis to show potential transmission opportunities. BMC Infect Dis 17(1):800. https://doi.org/10.1186/s12879-017-2895-6

John A, Alhmidi H, Cadnum JL, Jencson AL, Donskey CJ (2017) Contaminated portable equipment is a potential vector for dissemination of pathogens in the intensive care unit. Infect Control Hosp Epidemiol 38(10):1247-1249. https://doi. org/10.1017/ice.2017.160

Julian TR, Leckie JO, Boehm AB (2010) Virus transfer between fingerpads and fomites. J Appl Microbiol 109(6):1868-1874. https://doi.org/10.1111/j.1365-2672.2010.04814.x

Kaur S, Bherwani H, Gulia S, Vijay R, Kumar R (2020) Understanding COVID-19 transmission, health impacts and mitigation: timely social distancing is the key. Environ Dev Sustain. https ://doi.org/10.1007/s10668-020-00884-x

Kim D, Lee JY, Yang JS, Kim JW, Kim VN, Chang H (2020) The architecture of SARS-CoV-2 transcriptome. Cell 181(4):914921. https://doi.org/10.1016/j.cell.2020.04.011

Klompas M, Baker MA, Rhee C (2020) Airborne transmission of SARS-CoV-2: theoretical considerations and available evidence. JAMA. https://doi.org/10.1001/jama.2020.12458

Kramer A, Schwebke I, Kampf G (2006) How long do nosocomial pathogens persist on inanimate surfaces? A systematic review. BMC Infect Dis 6(1):130

Lan L, Xu D, Ye G, Xia C, Wang S, Li Y, Xu H (2020) Positive RTPCR test results in patients recovered from COVID-19. JAMA 323(15):1502-1503. https://doi.org/10.1001/jama.2020.2783

Lavezzo E, Franchin E, Ciavarella C, Cuomo-Dannenburg G, Barzon L, Del Vecchio C, Rossi L, Manganelli R, Loregian A, Navarin $\mathrm{N}$ et al (2020) Suppression of a SARS-CoV-2 outbreak in the Italian municipality of Vo'. Nature 584(7821):425-429. https:// doi.org/10.1038/s41586-020-2488-1

Li YH, Fan YZ, Jiang L, Wang HB (2020) Aerosol and environmental surface monitoring for SARS-CoV-2 RNA in a designated hospital for severe COVID-19 patients. Epidemiol Infect 148:e154. https://doi.org/10.1017/S0950268820001570

Linton NM, Kobayashi T, Yang Y, Hayashi K, Akhmetzhanov AR, Jung SM, Yuan B, Kinoshita R, Nishiura H (2020) Incubation Period and other epidemiological characteristics of 2019 novel coronavirus infections with right truncation: a statistical analysis of publicly available case data. J Clin Med. https://doi. org $/ 10.3390 /$ jcm 9020538

Lo IL, Lio CF, Cheong HH, Lei CI, Cheong TH, Zhong X, Tian Y, Sin NN (2020) Evaluation of SARS-CoV-2 RNA shedding in clinical specimens and clinical characteristics of 10 patients with COVID-19 in Macau. Int J Biol Sci 16(10):1698-1707. https://doi.org/10.7150/ijbs.45357

Long QX, Tang XJ, Shi QL, Li Q, Deng HJ, Yuan J, Hu JL, Xu W, Zhang Y, Lv FJ et al (2020) Clinical and immunological assessment of asymptomatic SARS-CoV-2 infections. Nat Med 26(8):1200-1204. https://doi.org/10.1038/s41591-020-0965-6

Lopez GU, Gerba CP, Tamimi AH, Kitajima M, Maxwell SL, Rose JB (2013) Transfer efficiency of bacteria and viruses from porous and nonporous fomites to fingers under different relative humidity conditions. Appl Environ Microbiol 79(18):57285734. https://doi.org/10.1128/AEM.01030-13

Lu R, Wu X, Wan Z, Li Y, Zuo L, Qin J, Jin X, Zhang C (2020) Development of a novel reverse transcription loop-mediated isothermal amplification method for rapid detection of SARSCoV-2. Virol Sin 35(3):344-347. https://doi.org/10.1007/s1225 0-020-00218-1
Mizumoto K, Kagaya K, Zarebski A, Chowell G (2020) Estimating the asymptomatic proportion of coronavirus disease 2019 (COVID19) cases on board the Diamond Princess cruise ship, Yokohama, Japan, 2020. Euro Surveill. https://doi.org/10.2807/1560-7917. es.2020.25.10.2000180

Mokhtari T, Hassani F, Ghaffari N, Ebrahimi B, Yarahmadi A, Hassanzadeh G (2020) COVID-19 and multiorgan failure: a narrative review on potential mechanisms. J Mol Histol. https://doi. org/10.1007/s10735-020-09915-3

Nishiura H, Kobayashi T, Miyama T, Suzuki A, Jung SM, Hayashi K, Kinoshita R, Yang Y, Yuan B, Akhmetzhanov AR et al (2020) Estimation of the asymptomatic ratio of novel coronavirus infections (COVID-19). Int J Infect Dis 94:154-155. https://doi. org/10.1016/j.ijid.2020.03.020

Noyce JO, Michels H, Keevil CW (2007) Inactivation of influenza A virus on copper versus stainless steel surfaces. Appl Environ Microbiol 73(8):2748-2750. https://doi.org/10.1128/AEM.01139 $-06$

Oelberg DG, Joyner SE, Jiang X, Laborde D, Islam MP, Pickering LK (2000) Detection of pathogen transmission in neonatal nurseries using DNA markers as surrogate indicators. Pediatrics 105(2):311-315. https://doi.org/10.1542/peds.105.2.311

Oran DP, Topol EJ (2020) Prevalence of asymptomatic SARS-CoV-2 Infection: a narrative review. Ann Intern Med 173(5):362-367. https://doi.org/10.7326/M20-3012

Pan Y, Zhang D, Yang P, Poon LLM, Wang Q (2020) Viral load of SARS-CoV-2 in clinical samples. Lancet Infect Dis 20(4):411412. https://doi.org/10.1016/S1473-3099(20)30113-4

Perera R, Tso E, Tsang OTY, Tsang DNC, Fung K, Leung YWY, Chin AWH, Chu DKW, Cheng SMS, Poon LLM et al (2020) SARSCoV-2 virus culture and subgenomic RNA for respiratory specimens from patients with mild coronavirus disease. Emerg Infect Dis. https://doi.org/10.3201/eid2611.203219

Qi L, Yang Y, Jiang D, Tu C, Wan L, Chen X, Li Z (2020) Factors associated with the duration of viral shedding in adults with COVID19 outside of Wuhan, China: a retrospective cohort study. Int J Infect Dis 96:531-537. https://doi.org/10.1016/j.ijid.2020.05.045

Qian GQ, Chen XQ, Lv DF, Ma AHY, Wang LP, Yang NB, Chen XM (2020a) Duration of SARS-CoV-2 viral shedding during COVID-19 infection. Infect Dis (Lond) 52(7):511-512. https:// doi.org/10.1080/23744235.2020.1748705

Qian GQ, Yang NB, Ding F, Ma AHY, Wang ZY, Shen YF, Shi CW, Lian X, Chu JG, Chen L et al (2020b) Epidemiologic and clinical characteristics of 91 hospitalized patients with COVID-19 in Zhejiang, China: a retrospective, multi-centre case series. QJM 113(7):474-481. https://doi.org/10.1093/qjmed/hcaa089

Rabenau HF, Cinatl J, Morgenstern B, Bauer G, Preiser W, Doerr HW (2005) Stability and inactivation of SARS coronavirus. Med Microbiol Immunol 194(1-2):1-6. https://doi.org/10.1007/s0043 0-004-0219-0

Razzini K, Castrica M, Menchetti L, Maggi L, Negroni L, Orfeo NV, Pizzoccheri A, Stocco M, Muttini S, Balzaretti CM (2020) SARSCoV-2 RNA detection in the air and on surfaces in the COVID-19 ward of a hospital in Milan, Italy. Sci Total Environ 742:140540. https://doi.org/10.1016/j.scitotenv.2020.140540

Rothe C, Schunk M, Sothmann P, Bretzel G, Froeschl G, Wallrauch C, Zimmer T, Thiel V, Janke C, Guggemos W et al (2020) Transmission of 2019-nCoV infection from an asymptomatic Contact in Germany. N Engl J Med 382(10):970-971. https://doi. org/10.1056/NEJMc2001468

Rusin P, Maxwell S, Gerba C (2002) Comparative surface-to-hand and fingertip-to-mouth transfer efficiency of gram-positive bacteria, gram-negative bacteria, and phage. J Appl Microbiol 93(4):585592. https://doi.org/10.1046/j.1365-2672.2002.01734.x

Ryu BH, Cho Y, Cho OH, Hong SI, Kim S, Lee S (2020) Environmental contamination of SARS-CoV-2 during the COVID-19 outbreak 
in South Korea. Am J Infect Control 48(8):875-879. https://doi. org/10.1016/j.ajic.2020.05.027

Sattar SA (2001) Survival of microorganisms on animate and inanimate surfaces and their disinfection. Association for Professionals in Infection Control and Epidemiology, Inc., Washington DC

Sizun J, Yu MW, Talbot PJ (2000) Survival of human coronaviruses 229E and OC43 in suspension and after drying onsurfaces: a possible source ofhospital-acquired infections. J Hosp Infect 46(1):55-60. https://doi.org/10.1053/jhin.2000.0795

Spicknall IH, Koopman JS, Nicas M, Pujol JM, Li S, Eisenberg JN (2010) Informing optimal environmental influenza interventions: how the host, agent, and environment alter dominant routes of transmission. PLoS Comput Biol 6(10):e1000969. https://doi. org/10.1371/journal.pcbi.1000969

Sun J, Xiao J, Sun R, Tang X, Liang C, Lin H, Zeng L, Hu J, Yuan R, Zhou P et al (2020) Prolonged persistence of SARS-CoV-2 RNA in Body Fluids. Emerg Infect Dis 26(8):1834-1838. https://doi. org/10.3201/eid2608.201097

Tan L, Ma B, Lai X, Han L, Cao P, Zhang J, Fu J, Zhou Q, Wei S, Wang $Z$ (2020) Air and surface contamination by SARS-CoV-2 virus in a tertiary hospital in Wuhan, China. Int J Infect Dis 99:3-7

Tang S, Mao Y, Jones RM, Tan Q, Ji JS, Li N, Shen J, Lv Y, Pan L, Ding P et al (2020) Aerosol transmission of SARS-CoV-2? Evidence, prevention and control. Environ Int 144:106039. https:// doi.org/10.1016/j.envint.2020.106039

The COVID-19 Investigation Team (2020) Clinical and virologic characteristics of the first 12 patients with coronavirus disease 2019 (COVID-19) in the United States. Nat Med 26(6):861-868. https ://doi.org/10.1038/s41591-020-0877-5

To KK, Tsang OT, Leung WS, Tam AR, Wu TC, Lung DC, Yip CC, Cai JP, Chan JM, Chik TS et al (2020) Temporal profiles of viral load in posterior oropharyngeal saliva samples and serum antibody responses during infection by SARS-CoV-2: an observational cohort study. Lancet Infect Dis 20(5):565-574. https://doi. org/10.1016/S1473-3099(20)30196-1

Tong ZD, Tang A, Li KF, Li P, Wang HL, Yi JP, Zhang YL, Yan JB (2020) Potential presymptomatic transmission of SARS-CoV-2, Zhejiang Province, China, 2020. Emerg Infect Dis 26(5):10521054. https://doi.org/10.3201/eid2605.200198

van Doremalen N, Bushmaker T, Munster VJ (2013) Stability of middle east respiratory syndrome coronavirus (MERS-CoV) under different environmental conditions. Euro Surveill. https://doi. org/10.2807/1560-7917.es2013.18.38.20590

van Doremalen N, Bushmaker T, Morris DH, Holbrook MG, Gamble A, Williamson BN, Tamin A, Harcourt JL, Thornburg NJ, Gerber SI et al (2020) Aerosol and surface stability of SARS-CoV-2 as compared with SARS-CoV-1. N Engl J Med 382(16):1564-1567. https://doi.org/10.1056/NEJMc2004973

Wang W, Xu Y, Gao R, Lu R, Han K, Wu G, Tan W (2020) Detection of SARS-CoV-2 in different types of clinical specimens. JAMA 323(18):1843-1844. https://doi.org/10.1001/jama.2020.3786

Warnes SL, Little ZR, Keevil CW (2015) Human coronavirus 229E remains infectious on common touch surface materials. mBio. https://doi.org/10.1128/mBio.01697-15

Wei L, Lin J, Duan X, Huang W, Lu X, Zhou J, Zong Z (2020) Asymptomatic COVID-19 patients can contaminate their surroundings: an environment sampling study. mSphere. https://doi.org/10.1128/ mSphere.00442-20

Wolfel R, Corman VM, Guggemos W, Seilmaier M, Zange S, Muller MA, Niemeyer D, Jones TC, Vollmar P, Rothe C et al (2020) Virological assessment of hospitalized patients with COVID2019. Nature 581(7809):465-469. https://doi.org/10.1038/s4158 6-020-2196-x
World Health Organization (2020a) Coronavirus disease (COVID-19) Pandemic Retrieved from https://www.who.int/emergencies/disea ses/novel-coronavirus-2019

World Health Organization (2020b) Modes of transmission of virus causing COVID-19: implications for IPC precaution recommendations: scientific brief. Retrieved from 27 Mar 2020 https://apps. who.int/iris/handle/10665/331601

World Health Organization (2020c) Statement on the meeting of the international health regulations (2005) emergency committee regarding the outbreak of novel coronavirus (2019-nCoV). Retrieved from https://www.who.int/news-room/detail/23-012020-statement-on-the-meeting-of-the-international-health-regul ations-(2005)-emergency-committee-regarding-the-outbreak-ofnovel-coronavirus-(2019-ncov)

World Health Organization (2020d) Transmission of SARS-CoV-2: implications for infection prevention precautions. Retrieved from https://www.who.int/publications/i/item/modes-of-transmissionof-virus-causing-covid-19-implications-for-ipc-precaution-recom mendations

Wu ZY (2020) Contribution of asymptomatic and pre-symptomatic cases of COVID-19 in spreading virus and targeted control strategies. Zhonghua Liu Xing Bing Xue Za Zhi 41(6):801-805. https ://doi.org/10.3760/cma.j.cn112338-20200406-00517

Xiao AT, Tong YX, Gao C, Zhu L, Zhang YJ, Zhang S (2020) Dynamic profile of RT-PCR findings from 301 COVID-19 patients in Wuhan, China: a descriptive study. J Clin Virol 127:104346. https ://doi.org/10.1016/j.jcv.2020.104346

Xiao AT, Tong YX, Zhang S (2020) Profile of RT-PCR for SARSCoV-2: a preliminary study from 56 COVID-19 patients. Clin Infect Dis. https://doi.org/10.1093/cid/ciaa460

Xiao F, Sun J, Xu Y, Li F, Huang X, Li H, Zhao J, Huang J, Zhao J (2020) Infectious SARS-CoV-2 in feces of patient with severe COVID-19. Emerg Infect Dis 26(8):1920-1922. https://doi. org/10.3201/eid2608.200681

Xie X, Li Y, Chwang AT, Ho PL, Seto WH (2007) How far droplets can move in indoor environments-revisiting the wells evaporationfalling curve. Indoor Air 17(3):211-225. https://doi.org/10.111 1/j.1600-0668.2007.00469.x

Xu K, Chen Y, Yuan J, Yi P, Ding C, Wu W, Li Y, Ni Q, Zou R, Li X et al (2020) Factors associated with prolonged viral RNA shedding in patients with coronavirus disease 2019 (COVID-19). Clin Infect Dis 71(15):799-806. https://doi.org/10.1093/cid/ciaa351

Yan C, Cui J, Huang L, Du B, Chen L, Xue G, Li S, Zhang W, Zhao L, Sun Y et al (2020) Rapid and visual detection of 2019 novel coronavirus (SARS-CoV-2) by a reverse transcription loop-mediated isothermal amplification assay. Clin Microbiol Infect 26(6):773779. https://doi.org/10.1016/j.cmi.2020.04.001

Yin G, Jin H (2020) Comparison of transmissibility of coronavirus between symptomatic and asymptomatic patients: reanalysis of the Ningbo COVID-19 data. JMIR Public Health Surveill 6(2):e19464. https://doi.org/10.2196/19464

Yu L, Wu S, Hao X, Dong X, Mao L, Pelechano V, Chen WH, Yin X (2020) Rapid detection of COVID-19 coronavirus using a reverse transcriptional loop-mediated isothermal amplification (RTLAMP) diagnostic platform. Clin Chem 66(7):975-977. https:// doi.org/10.1093/clinchem/hvaa102

Zaim S, Chong JH, Sankaranarayanan V, Harky A (2020) COVID-19 and multiorgan response. Curr Probl Cardiol 45(8):100618. https ://doi.org/10.1016/j.cpcardiol.2020.100618

Zhang J, Wang S, Xue Y (2020) Fecal specimen diagnosis 2019 novel coronavirus-infected pneumonia. J Med Virol 92(6):680-682. https://doi.org/10.1002/jmv.25742

Zhang W, Du RH, Li B, Zheng XS, Yang XL, Hu B, Wang YY, Xiao GF, Yan B, Shi ZL et al (2020) Molecular and serological investigation of 2019-nCoV infected patients: implication of multiple 
shedding routes. Emerg Microbes Infect 9(1):386-389. https://doi. org/10.1080/22221751.2020.1729071

Zheng S, Fan J, Yu F, Feng B, Lou B, Zou Q, Xie G, Lin S, Wang R, Yang X et al (2020) Viral load dynamics and disease severity in patients infected with SARS-CoV-2 in Zhejiang province, China, January-March 2020: retrospective cohort study. BMJ 369:m1443. https://doi.org/10.1136/bmj.m1443

Zhou F, Yu T, Du R, Fan G, Liu Y, Liu Z, Xiang J, Wang Y, Song B, $\mathrm{Gu} X$ et al (2020) Clinical course and risk factors for mortality of adult inpatients with COVID-19 in Wuhan, China: a retrospective cohort study. Lancet 395(10229):1054-1062. https://doi. org/10.1016/S0140-6736(20)30566-3

Zhou J, Otter JA, Price JR, Cimpeanu C, Garcia DM, Kinross J, Boshier PR, Mason S, Bolt F, Holmes AH et al (2020) Investigating SARS-CoV-2 surface and air contamination in an acute healthcare setting during the peak of the COVID-19 pandemic in London. Clin Infect Dis. https://doi.org/10.1093/cid/ciaa905
Zhou R, Li F, Chen F, Liu H, Zheng J, Lei C, Wu X (2020) Viral dynamics in asymptomatic patients with COVID-19. Int J Infect Dis 96:288-290. https://doi.org/10.1016/j.ijid.2020.05.030

Zou L, Ruan F, Huang M, Liang L, Huang H, Hong Z, Yu J, Kang M, Song Y, Xia J et al (2020) SARS-CoV-2 viral load in upper respiratory specimens of infected patients. N Engl J Med 382(12):11771179. https://doi.org/10.1056/NEJMc2001737

Zuo Z, de Abin M, Chander Y, Kuehn TH, Goyal SM, Pui DY (2013) Comparison of spike and aerosol challenge tests for the recovery of viable influenza virus from non-woven fabrics. Influenza Other Respir Viruses 7(5):637-644. https://doi.org/10.1111/irv.12095

Publisher's Note Springer Nature remains neutral with regard to jurisdictional claims in published maps and institutional affiliations. 